\title{
Carbohydrate deficient glycoprotein syndrome type II: a deficiency in Golgi localised $\mathrm{N}$-acetyl-glucosaminyltransferase II
}

\author{
J Jaeken, H Schachter, H Carchon, P De Cock, B Coddeville, G Spik
}

\begin{abstract}
The carbohydrate deficient glycoprotein (CDG) syndromes are a family of genetic multisystemic disorders with severe nervous system involvement. This report is on a child with a CDG syndrome that differs from the classical picture but is very similar to a patient reported in 1991. Both these patients are therefore designated CDG syndrome type II. Compared with type I patients they have a more severe psychomotor retardation but no peripheral neuropathy nor cerebellar hypoplasia. The serum transferrin isoform pattern obtained by isoelectric focusing showed disialotransferrin as the major fraction. The serum disialotransferrin, studied in the present patient, contained two moles of truncated monoantennary Sialyl-Gal-GlcNAc$\operatorname{Man}(\alpha 1 \rightarrow 3)[\operatorname{Man}(\alpha 1 \rightarrow 6)] \operatorname{Man}(\beta 1 \rightarrow 4) G 1 c N$ $\operatorname{Ac}(\beta 1 \rightarrow 4)$ GlcNAc-Asn per mole of transferrin. A profoundly deficient activity of the Golgi enzyme $\boldsymbol{N}$-acetylglucosaminyltransferase II (EC 2.4.1.143) was demonstrated in fibroblasts.

(Arch Dis Child 1994; 71: 123-127)
\end{abstract}

Carbohydrate deficient glycoprotein (CDG) syndromes are genetic multisystemic diseases first reported in 1980 by Jaeken et al. They are characterised by a deficiency in the carbohydrate moiety of secretory glycoproteins, lysosomal enzymes, and probably also membranous glycoproteins (for reviews see Jaeken et $a l^{1-3}$ ). The nervous system is always moderately to severely affected and most other organs are involved to a variable degree. A reliable diagnostic test is isoelectric focusing of serum transferrin showing a cathodal shift as a consequence of the partial sialic acid deficiency. ${ }^{45}$ The primary defect has yet to be determined. Recently we have reported on a CDG syndrome in an Iranian girl with distinctive clinical and biochemical features. ${ }^{6}$ Here we describe a Belgian boy with remarkably similar findings. These two patients represent a separate variant of CDG syndrome designated type II as opposed to the 'classic' type I. We have demonstrated that the activity of UDP-GlcNAc: $\alpha 6-$ $D$-mannoside $\quad \beta 1 \rightarrow 2-N$-acetylglucosaminyltransferase II (GnT II; EC 2.4.1.143) is severely decreased in patient fibroblasts thus identifying this disease as a Golgi disorder. A short report on this patient has been published elsewhere. ${ }^{7}$

\section{Case report}

The patient, a Belgian boy, was born in 1983 after a normal pregnancy and delivery. His birth weight was $3250 \mathrm{~g}$, length $50 \mathrm{~cm}$, and head circumference $35 \mathrm{~cm}$. He had a younger healthy brother; the parents were not related. The father's height was on the 3rd centile and head circumference on the 90th centile; he showed some facial dysmorphism with a short neck but was otherwise normal. From birth the patient was hypotonic. He showed dysmorphic features: a hook nose, large dysplastic ears in oblique position, thin lips, prognathia of the maxilla, short neck, proximal implantation of the thumbs, and irregular position of the toes. There was a cardiac murmur due to a small ventricular septal defect. Psychomotor development was severely retarded: visual contact appeared around 16 months (but remained poor), he could sit without support at 2.5 years, reach for an object at 4.5 years, and take a few steps without support at 7 years. At the age of 10 years his speech was limited to a few monotonous sounds. Growth was normal until the age of 2 years but then progressively slowed down; at 10 years his height was $114 \mathrm{~cm}$ (3rd centile $125 \mathrm{~cm}$, weight $18 \mathrm{~kg}$ (3rd centile 23 $\mathrm{kg}$ ), and his head circumference has remained between the 25 th and 50 th centiles. From the first weeks he suffered from gastrointestinal problems (regurgitation due to volvulus of the stomach, and obstipation) as well as from frequent infections particularly of the upper airways. Epilepsy developed at the age of 6 years and was only partially controlled by methylphenobarbitone and sodium valproate. He showed a striking stereotypic behaviour: hand-mouth and handwashing movements, head turning, knocking on his cheeks, and rocking. After the age of 1 year other morphological characteristics were noted: a midfrontal capillary haemangioma, gum hypertrophy and unusually large teeth, thoracolumbar kyphoscoliosis, hollowed breast, hypotrophic distal limbs, and flat feet. Deep tendon reflexes were normal. The following diagnoses have been put forward successively: Holt-Oram syndrome, trichorhinophalangeal syndrome (in the first years his hair was sparse and thin), and Smith-Lemli-Opitz syndrome. The correct diagnosis was finally made at $9 \cdot 5$ years when, on occasion of a gum bleeding, investigation of the coagulation revealed the typical coagulopathy of CDG syndrome. ${ }^{8}$ Clinical examination at that time also showed small testes $(1 \mathrm{ml})$. 


\section{Laboratory investigations}

Normal results were obtained for peripheral blood indices and for serum electrolytes, creatinine, uric acid, amino acids, albumin, cholesterol, alkaline phosphatase, glutamic pyruvic transaminase, $\gamma$-glutamyltransaminase, IgA, IgM, transferrin, ceruloplasmin, creatine kinase, arylsulphatase A activity, coagulation factor VIII and $\mathrm{X}$ activities, von Willebrand factor antigen, ristocetin cofactor, fibrinogen, complement factors $\mathrm{Clq}, \mathrm{C} 3 \mathrm{c}$, $\mathrm{C} 4, \mathrm{C} 5$, and $\mathrm{C} 1$ esterase inhibitor, follicle stimulating hormone, luteinising hormone, prolactin, growth hormone, free thyroxine, total triiodothyronine, thyroid stimulating hormone, insulin, and cortisol.

Lowered serum values were found for a large number of glycoproteins (table). There was an increase of serum glutamic oxaloacetic transaminase: 80-160 U/1 (normal range $<40$ ), of complement factor $\mathrm{C} 3 \mathrm{~d}: 6 \cdot 2 \%(0 \cdot 6-3 \cdot 1)$, and of the activated partial thromboplastin time: 71 seconds (24-38). There was a decrease of the thrombin time: 15 seconds (18-24), serum iron: $7.5 \mu \mathrm{mol} / 1(14.3-21.5)$, total thyroxine: $51.5 \mathrm{nmol} / 1$ (70.8-154), reverse triiodothyronine: $0.20 \mathrm{nmol} / 1(0.31-0.77)$, and $25-$ hydroxyvitamin D: $12.5 \mathrm{nmol} / 1$ (17.5-149.8). Routine urine analysis and concentration of cerebrospinal fluid protein were normal.

In lymphocytes activities of the lysosomal enzymes arylsulphatase A, $\alpha$-L-fucosidase, $\beta$-galactosidase, $\alpha$-glucosidase, $\beta$-glucuronidase, $N$-acetyl $\beta$-hexosaminidase, and $\alpha$-mannosidase were normal. Chromosomal analysis in lymphocytes and fibroblasts was normal. It has to be noted that lymphocyte culture was successful only at the seventh attempt.

Radiological examination of the skeleton showed osteopenia, luxation of the left radius, bilateral coxa valga, gracile long bones, and hemivertebra of C6. Electromyography, nerve conduction velocity, and evoked potentials gave normal results. On ophthalmological examination there were somewhat pale and hazy papillae at 9 years and decreased amplitude of the electroretinogram. Electroencephalography showed a slow basal rhythm and paroxysmal activity. Magnetic resonance imaging of the brain was normal. Liver biopsy was refused.

\section{Methods}

ISOELECTRIC FOCUSING OF SERUM

TRANSFERRIN

This was performed as previously described. ${ }^{49}$

STRUCTURAL STUDIES OF SERUM TRANSFERRIN Serum transferrin was isolated by immunoaffinity chromatography and transferrin subfractions were separated by ion exchange on a Mono $Q$ HR 5/5 column using a fast protein liquid chromatography technique. ${ }^{10}$ Monosaccharide molar ratios were determined after methanolysis and trimethylsilylation. ${ }^{11}$ ${ }^{1} \mathrm{H}$-nuclear magnetic resonance ${ }^{1213}$ and electrospray mass spectrometry ${ }^{14}$ were performed on the isolated transferrin.

\section{FIBROBLAST CULTURE AND ENZYME}

EXTRACTION

Fibroblasts were grown in $100 \mathrm{~mm}$ tissue culture dishes to a confluent monolayer (about $10^{6} \mathrm{cells} / \mathrm{dish}$ ) in alpha minimal essential medium ( $\alpha$-MEM) containing glucose, $10 \%$ fetal calf serum, antibiotics, and amphotericin. The medium was removed, the cells were washed with citrate saline EDTA $(0.2 \%)$, trypsin was added to the dish, followed by $5 \mathrm{ml}$ $\alpha-M E M / 10 \%$ fetal calf serum when the cells were rounded up. The cells were rinsed with the same solution and centrifuged at $1000 \mathrm{rpm}$ for 5 minutes. The cells were washed with $5 \mathrm{ml}$ phosphate buffered saline (PBS), centrifuged at $1000 \mathrm{rpm}$ for 5 minutes, the PBS was removed, and the cell pellets were frozen at $-70^{\circ} \mathrm{C}$. The enzyme extract was prepared by dissolving the frozen pellets in an equal volume of ice cold $0 \cdot 1 \mathrm{M} 2-[\mathrm{N}$-morpholino] ethanesulfonic acid (MES), $\mathrm{pH} 6.5,1 \%$ Triton $\mathrm{X}-100,0.2 \mathrm{M}$ sodium chloride $(\mathrm{NaCl})$, and $0.02 \%$ sodium azide. Protein concentrations were determined on the Triton extracts with the BCA Protein Assay Reagent (Pierce) using bovine serum albumin as standard.

\section{ENZYME ASSAYS}

GnT I (Uridine diphosphate (UDP)-GlcNAc: $\alpha 3-$ $D$-mannoside $\beta-1,2-\mathrm{N}$-acetylglucosaminyltrans-

ferase I; EC 2.4.1.101)

The reaction mixture in the enzyme assay ${ }^{15}$ contained, in a total volume of $0.020 \mathrm{ml}, 0.25$ $\mathrm{mM} \mathrm{M}$-octyl (Man $\alpha 1 \rightarrow 6[$ Man $\alpha 1 \rightarrow 3]$ Man $\beta$ octyl, synthesised in the laboratory of Professor H Paulsen, Hamburg, Germany), 0 1 M MES, $\mathrm{pH} 6.5,0.1 \mathrm{M} \mathrm{NaCl}, 20 \mathrm{mM}$ manganese chloride, $0.5 \mathrm{mM}$ UDP- $\left[{ }^{3} \mathrm{H}\right] \mathrm{GlcNAc}(10000$ disintegrations $/$ minute $(\mathrm{dpm}) / \mathrm{nmol}), \quad 0 \cdot 25 \%$ Triton X-100, $10 \mathrm{mM}$ AMP, 0.2 M GlcNAc, $0.02 \%$ sodium azide, and enzyme extract $(0 \cdot 1-0.3 \mathrm{mg})$. After incubation at $37^{\circ} \mathrm{C}$ for 30-60 minutes, the reaction was stopped with $0.5 \mathrm{ml}$ water and frozen at $-70^{\circ} \mathrm{C}$. Product formation was assayed by adsorption to Sep-Pak $\mathrm{C}_{18}$ reverse phase cartridges (Waters), elution with $3.0 \mathrm{ml}$ methanol ${ }^{16}$ and scintillation counting. Values were corrected for radioactivity obtained in control incubations lacking acceptor substrate.

\section{GnT II (UDP-GlcNAc: $\alpha 6-D-m a n n o s i d e$} $\beta-1,2-\mathrm{N}$-acetylglucosaminyltransferase II; EC 2.4.1.143)

Exactly as for GnT $I^{1718}$ except that the substrate is $0.25 \mathrm{mM} \mathrm{GnM}_{3}$-octyl (Man $\alpha 1 \rightarrow$ $6[$ GlcNAc $\beta 1 \rightarrow 2$ Man $\alpha 1 \rightarrow 3$ ] Man $\beta$-octyl, synthesised in the laboratory of Professor $\mathrm{H}$ Paulsen, Hamburg, Germany).

\section{GalT (UDP-Gal:GlcNAc}

$\beta$-1,4-galactosyltransferase; EC 2.4.1.38/90)

The reaction mixture in the enzyme assay contains, in a total volume of $0.020 \mathrm{ml}, 20 \mathrm{mM}$ GlcNAc, $0 \cdot 1 \mathrm{M}$ MES, pH $6 \cdot 5,0 \cdot 1 \mathrm{M} \mathrm{NaCl}$, $20 \mathrm{mM}$ manganese chloride, $4.0 \mathrm{mM}$ UDP$\left[{ }^{3} \mathrm{H}\right] \mathrm{Gal}(660 \mathrm{dpm} / \mathrm{nmol}), 0 \cdot 25 \%$ Triton 


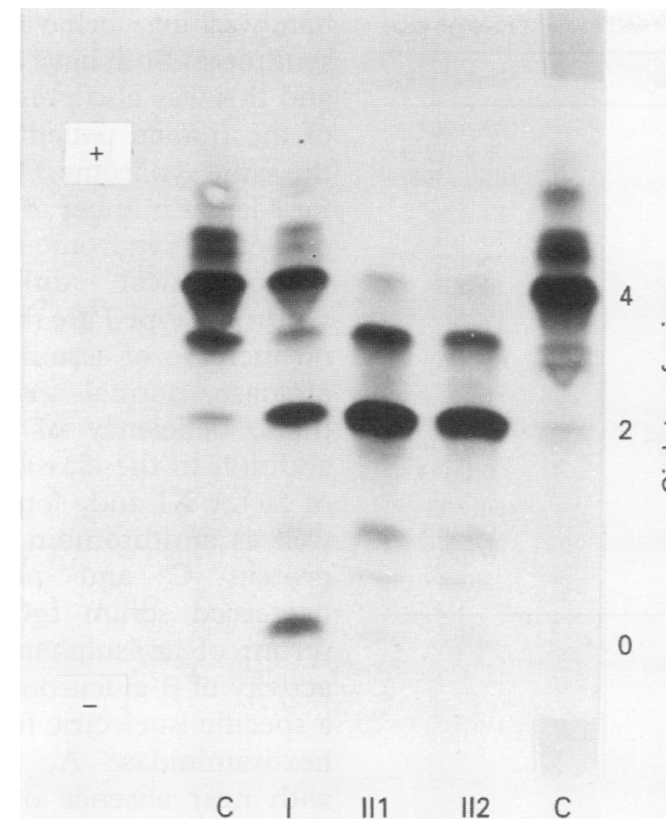

Figure 1 Isoelectric focusing pattern of serum transferrin in controls (C), CDG syndrome type I (I) and in both patients with CDG syndrome type II (III and II2).

$\mathrm{X}-100,0 \cdot 02 \%$ sodium azide, and enzyme extract $(0 \cdot 1-0.3 \mathrm{mg})$. After incubation at $37^{\circ} \mathrm{C}$ for 30 minutes, the reaction was stopped with $0.5 \mathrm{ml}$ water and frozen at $-70^{\circ} \mathrm{C}$. Product formation was assayed by passing the reaction mixture through a $1 \mathrm{ml}$ column of AG $1-\mathrm{X} 8$ (chloride form) equilibrated with water. The

A

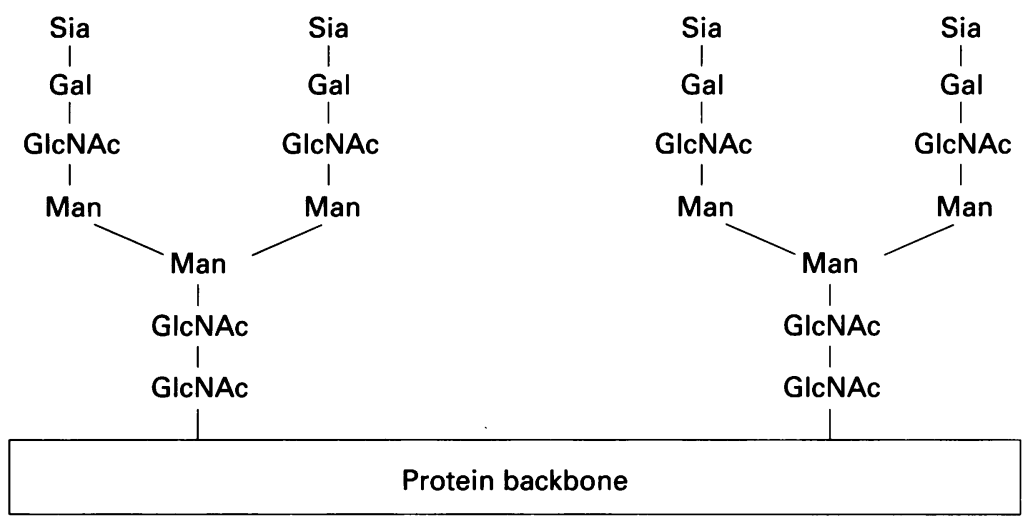

B

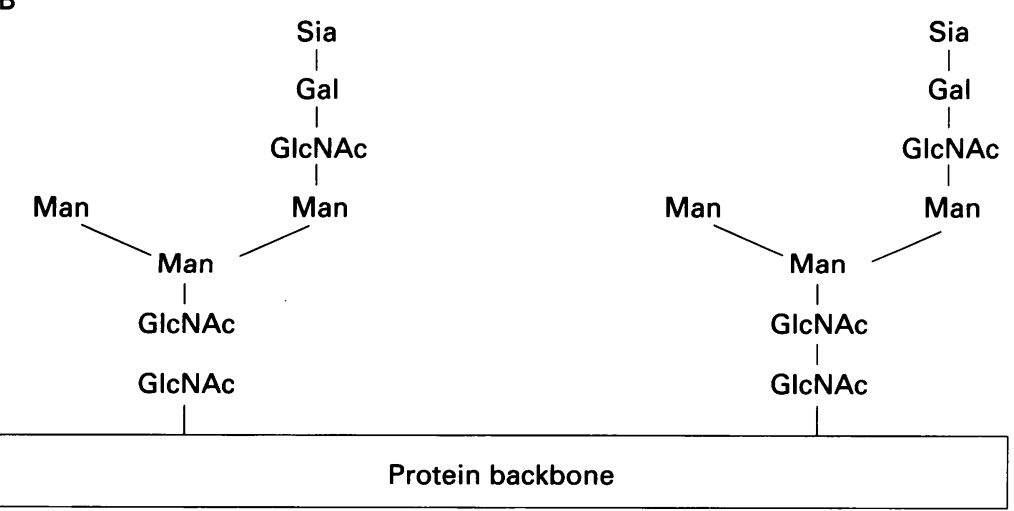

Figure 2 Structure of the glycan moieties of $(A)$ normal serum tetratransferrin and $(B)$ serum disialotransferrin of the patient. Sia: sialic acid, Gal: galactose, GlcNAc: N-acetylglucosamine, Man: mannose. column was washed with $2 \mathrm{ml}$ water and the radioactivity in the eluate was counted in scintillation fluid. Values are corrected for radioactivity obtained in control incubations lacking acceptor substrate.

\section{Results}

Isoelectric focusing of serum transferrin of the patient showed a markedly abnormal pattern (fig 1). Compared with controls tetrasialotransferrin was nearly absent. There was a large increase of disialotransferrin, and a band was present at the monosialotransferrin position as well as a faint additional (unidentified) band between the position of monosialotransferrin and asialotransferrin. The parents of the patient showed a normal pattern. Type I patients show a distinctly different pattern with a less pronounced decrease of tetrasialotransferrin, smaller increase of disialotransferrin, no additional band, and an important asialotransferrin fraction (fig 1), while type III patients show an approximately equal increase of tri-, di-, mono- and asialotransferrin with appreciable amounts of normal isoforms. ${ }^{19}$

Figure 2A shows the structures of the two $N$-glycans previously found in serum tetrasialotransferrin from normal controls. ${ }^{20}$ Analysis by ${ }^{1} \mathrm{H}$-nuclear magnetic resonance and electrospray mass spectrometry of purified disialotransferrin from the patient showed the presence of two truncated monoantennary monosialylated $N$-glycans per mole of transferrin (fig 2B). The difference between the molecular weights of normal serum tetrasialotransferrin (79 588) and disialotransferrin from the patient $(78272)$ indicates that two moles of the trisaccharide chain $\alpha-N e u A c(2 \rightarrow 6) \beta-D-G a l(1 \rightarrow 4) \beta-D-G l c N A c$ are missing per mole of transferrin.

The activities (expressed as $\mathrm{nmol} / \mathrm{mg} /$ hour) of $\mathrm{GnT} I(5 \cdot 3,5 \cdot 7$ respectively) and Gal T (17, 18 respectively) in fibroblast extracts from the present patient and the previously reported patient were in the normal range while GnT II activities in these extracts were respectively 1.4 and $0.9 \%$ of the mean activity in control fibroblast extracts (patients: $0.03,0.02$, respectively; controls $2 \cdot 2 \pm 1 \cdot 0 ; n=4$ or more for all assays). GnT II assays carried out on mixtures of Triton X-100 extracts from control and patient fibroblasts indicated that the almost complete absence of enzyme activity in the patient extracts was not due to the presence of an enzyme inhibitor.

\section{Discussion}

The present patient and a recently reported Iranian child ${ }^{6}$ show a very similar CDG syndrome with, however, some clinical and biochemical differences from the classic picture. We have therefore proposed to label this CDG syndrome type II as opposed to type I in the other patients. ${ }^{7}$ More specifically, both patients have a more severe psychomotor retardation, no peripheral neuropathy, and a normal cerebellum on magnetic resonance imaging. They show a stereotypic 
Decreased serum glycoprotein concentrations and activities in the patient

\begin{tabular}{|c|c|c|}
\hline & Observed value & Normal range \\
\hline $\begin{array}{l}\text { Apo B }(\mathrm{mg} / \mathrm{dl}) \\
\text { Haptoglobin }(\mu \mathrm{mol} / \mathrm{l}) \\
\text { Thyroxine-binding globulin }(\mathrm{nmol} / \mathrm{l})\end{array}$ & $\begin{array}{c}41 \\
2 \cdot 2 \\
139 \cdot 0\end{array}$ & $\begin{array}{c}80-120 \\
5 \cdot 9-17 \cdot 6 \\
180 \cdot 1-308 \cdot 9\end{array}$ \\
\hline $\begin{array}{l}\text { Coagulation factor IX }(\%) \\
\text { Coagulation factor XI }(\%) \\
\text { Coagulation factor XII }(\%) \\
\text { Antithrombin III (\%) } \\
\text { Protein C }(\%) \\
\text { Protein S }(\%) \\
\text { Heparin cofactor II }(\%)\end{array}$ & $\begin{array}{l}48 \\
22 \\
36 \\
28 \\
30 \\
63 \\
22\end{array}$ & $\begin{array}{l}70-130 \\
70-130 \\
70-130 \\
70-130 \\
70-130 \\
70-130 \\
60-170\end{array}$ \\
\hline $\begin{array}{l}\text { IgG } \\
\mathrm{CH} 50(\mathrm{U} / \mathrm{ml}) \\
\mathrm{C} 2(\mathrm{~g} / \mathrm{l}) \\
\mathrm{C} 3 \mathrm{~A}(\mathrm{~g} / \mathrm{l})\end{array}$ & $\begin{array}{l}\text { Decreased } \\
162237 \\
0.004,0.007 \\
0.06\end{array}$ & $\begin{array}{l}300-500 \\
0.01-0.03 \\
0 \cdot 1-0 \cdot 4\end{array}$ \\
\hline $\begin{array}{l}\text { IGF-I (ng/ml) } \\
\beta \text {-Galactosidase activity }(\mu \mathrm{mol} / / / \mathrm{min}) \\
\beta \text {-Glucuronidase activity }(\mu \mathrm{mol} / / \mathrm{min}) \\
\alpha_{1} \text {-Antitrypsin }(\mathrm{g} / \mathrm{l})\end{array}$ & $\begin{array}{l}23 \\
0 \cdot 07 \\
0 \cdot 43 \\
1.5\end{array}$ & $\begin{array}{l}100-300 \\
0 \cdot 1-0 \cdot 8 \\
0 \cdot 5-7 \\
2 \cdot 0-4 \cdot 0\end{array}$ \\
\hline
\end{tabular}

$\star U p$ to the age of 6 years.
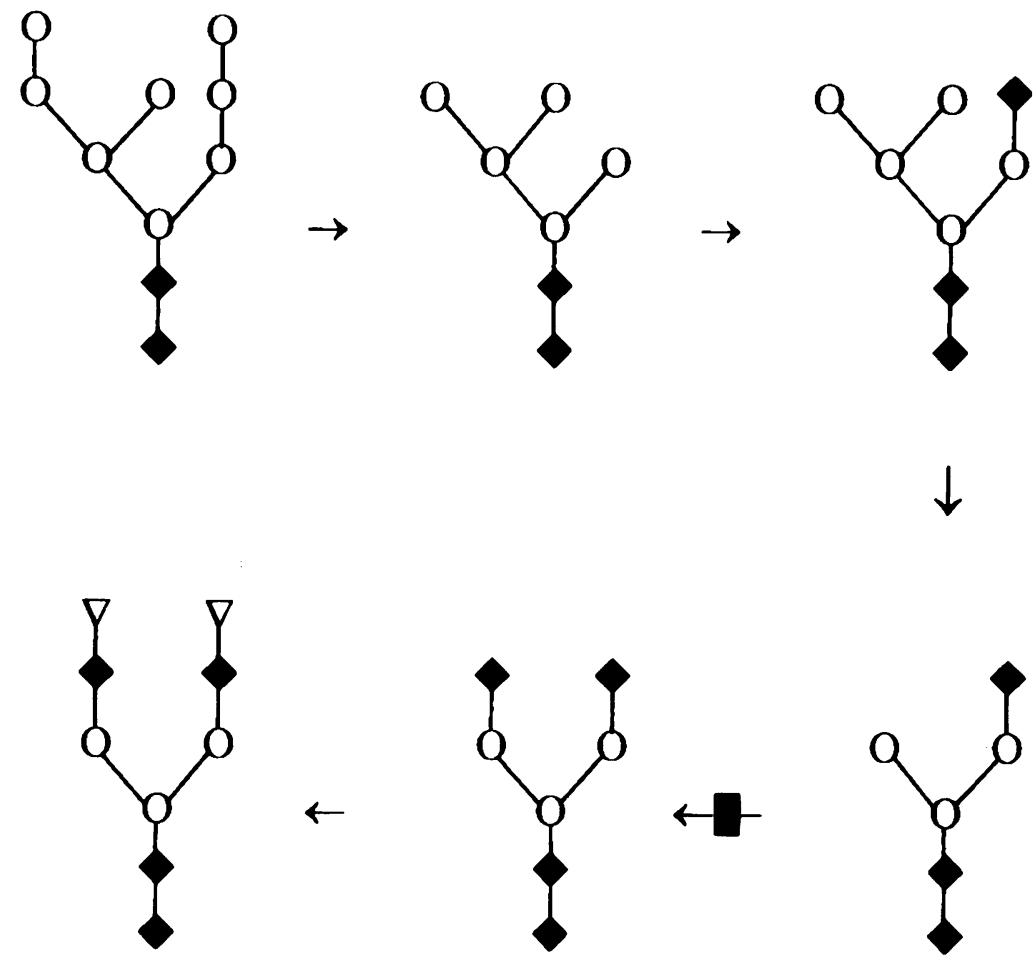

$\sqrt{2}$
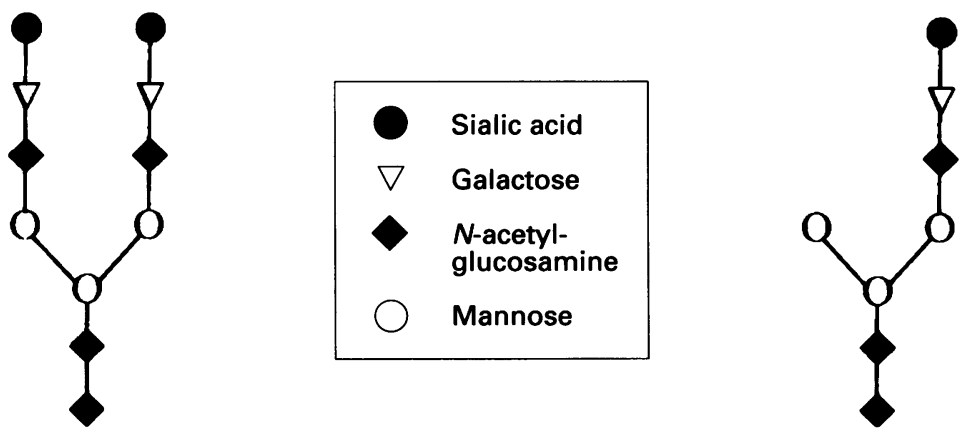

Figure 3 Scheme of the glycosylation pathway in the Golgi apparatus. Bar indicates the enzymatic defect (GnT II or IUDP-GlcNAc: $\alpha 6-\mathrm{D}-$ mannoside

$\beta-1,2-\mathrm{N}$-acetylglucosaminyltransferase II (EC 2.4.1.143) deficiency]. Empty arrows indicate pathway leading to disialotransferrin. handwashing behaviour as seen in Rett's syndrome. Both have a ventricular septal defect and this was also present in a deceased sibling of the Iranian patient who very probably had the same syndrome. ${ }^{6}$ We have of course to wait for a larger number of patients to know if this is part of the syndrome or just a coincidence.

Biochemical differences from CDG syndrome type I are the absence of proteinuria, no increase of serum glutamic pyruvic transaminase, normal serum albumin concentrations, deficiency of clotting factor XII (in addition to the classic pattern with deficiency of factor XI and, sometimes, of factor IX, as well as antithrombin III, heparin cofactor II, protein $\mathrm{C}$ and protein $\mathrm{S}^{8}$ ), transiently decreased serum IgG, a normal activity in serum of arylsulphatase $A$, and a decreased activity of $\beta$-glucuronidase (table). They show a specific isoelectric focusing pattern of serum hexosaminidase $\mathrm{A}$, and of sialotransferrins with near absence of tetra- and asialotransferrins, and a marked increase of disialotransferrin (fig 1).

The glycan structure of serum disialotransferrin, determined in the present patient, was similar to that of the monantennary $\mathrm{N}$-acetyllactosamine type glycan accumulating in erythrocytes from patients with congenital dyserythropoietic anaemia type II (HEMPAS) ${ }^{21}$ and differed from the structure of the disialylated diantennary ${ }^{20}$ and the trisialylated triantennary ${ }^{22} \quad \mathrm{~N}$-acetyllactosamine type glycans previously reported in normal serum transferrin. Lymphocyte extracts from two HEMPAS patients were reported to have GnT II activities at 11 and $30 \%$ of normal values. ${ }^{21}$ The same enzymatic defect was therefore postulated to be present in CDG syndrome type II. We were able to confirm our hypothesis by showing a severe deficiency of $\mathrm{N}$-acetylglucosaminyltransferase II in fibroblasts of the present and the previously reported patient.

The common (Man) ${ }_{3}(\mathrm{GlcNAc})_{2}$-Asn core structure of complex $N$-glycans is substituted with branches or antennae which are initiated by the sequential action of six $\mathrm{N}$-acetylglucosaminyltransferases (GlcNAc-transferases I-VI). ${ }^{23-25} \mathrm{GnT}$ II catalyses the conversion of Man $\alpha 1 \rightarrow 6[$ GlcNAc $\beta 1 \rightarrow 2$ Man $\alpha 1 \rightarrow 3]$ Man $\beta-R$ to $\operatorname{GlcNAc} \beta 1 \rightarrow 2 \mathrm{Man} \alpha 1 \rightarrow 6[\mathrm{GlcNAc} \beta 1 \rightarrow$ $2 \operatorname{Man} \alpha 1 \rightarrow 3] \operatorname{Man} \beta-R$ where $R$ is $1 \rightarrow 4$ GlcNAc $\beta 1 \rightarrow 4$ GlcNAc-Asn-X. Prior $\mathrm{GnT} I$ action is essential for the actions of $\mathrm{GnT}$ II, III, and IV whereas prior GnT II action is essential for the action of GnT V; complex $N$-glycan synthesis cannot occur until GnT I and II have acted. Patients lacking GnT II will therefore be unable to add any GlcNAc residues to the Man $\alpha 1 \rightarrow 6$ arm of the $N$-glycan core. However, the substrate of $N$-acetylglucosaminyltransferase II can be further glycosylated by galactosyltransferase and sialyltransferase on the single antenna containing $N$-acetylglucosamine (fig 3 ). This monosialoglycan is present twice on the transferrin protein thus resulting in the disialotransferrin fraction as shown.

The human GnT II gene (MGAT2) has 
been cloned and is on chromosome $14 \mathrm{q} 21 .{ }^{26}$ Genetic analysis of the CDG syndrome type II fibroblasts with human GnT II probes is under way.

In conclusion, this is the first of the three known CDG syndrome types whose basic defect has been elucidated.

We thank Miss E Jansen for expert technical assistance, Professor Jean-Jacques Cassiman, Leuven, Belgium, fo cultivating the fibroblasts, and Professor Jos Kint, Ghent, Belgium, for determination of lysosomal enzyme activities in serum and lymphocytes. This work was supported by the Belgian Nationaal Fonds voor Wetenschappelijk Onderzoek (grant 3.0115.94), the Université des Sciences et Technologies de Lille and the Centre National de la Recherche Scientifique de Lille and the Centre National de la Recherche Scientifique Verbert) (grant INSERM 930507)

1 Jaeken J, Stibler H, Hagberg B. The carbohydrate-deficient glycoprotein syndrome: a new inherited multisystemic disease with severe nervous system involvement. Acta Paediatr Scand Suppl 1991; 375 (monograph).

2 Jaeken J, Carchon H. The carbohydrate-deficient glycoprotein syndromes: an overview. $\mathcal{F}$ Inherited Metab Dis 1993; 16: 813-20.

3 Jaeken J, Carchon H, Stibler H. The carbohydrate-deficient glycoprotein syndromes: pre-Golgi and Golgi disorders? Glycobiology 1993; 3: 423-8.

4 Jaeken J, van Eijk HG, van der Heul C, Corbeel L, Eeckels $R$, Eggermont E. Sialic acid-deficient serum and cerebrospinal fluid transferrin in a newly recognized genetic syndrome. Clin Chim Acta 1984; 144: 245-7.

5 Stibler H, Jaeken J. Carbohydrate-deficient serum transferrin in a new systemic hereditary syndrome. Arch Dis Child 1990; 65: 107-11.

6 Ramaekers VT, Stibler H, Kint J, Jaeken J. A new variant of the carbohydrate-deficient glycoproteins syndrome. Inherited Metab Dis 1991; 14: 385-8.

7 Jaeken J, De Cock P, Stibler H, et al. Carbohydrate-deficient glycoprotein syndrome type II. $\mathcal{F}$ Inherited Metab Dis 1993; 16: 1041

8 Van Geet C, Jaeken J. A unique pattern of coagulation abnormalities in carbohydrate-deficient glycoprotein syndrome. Pediatr Res 1993; 33: 540-1.

9 van Eijk HG, van Noort WL, Dubelaar ML, van der Heul C. The microheterogeneity of human transferrins in biological fluids. Clin Chim Acta 1984; 132: 167-71.

10 Campion B, Léger D, Wieruszeski JM, Montreuil J, Spik G. Presence of fucosylated triantennary, tetraantennary and pentaantennary glycans in transferrin synthesized by the pentaantennary glycans in transferrin synthesized by the 1989; 184: 405-13.

11 Kamerling JP, Gerwig GJ, Vliegenthart JFG, Clamp JR. Characterization by gas-liquid chromatography-mass spectrometry and proton-magnetic resonance spectro- scopy of pertrimethylsilyl methyl glycosides obtained in the methanolysis of glycoproteins and glycopeptides. the methanolysis of glycopro

12 Dorland L, Haverkamp BL, Schut BL, et al. The structure of the asialo-carbohydrate units of human transferrin as proven by $360 \mathrm{MHz}$ proton magnetic resonance spectroscopy. FEBS Lett 1977; 77: 15-20.

13 Vliegenthart JFG, Dorland L, van Halbeek H. Highresolution, ${ }^{1} \mathrm{H}$-nuclear magnetic resonance spectroscopy as a tool in the structural analysis of carbohydrates related to glycoproteins. Adv Carbohydr Chem Biochem 1983; 41: 209-374

14 Edmonds CG, Smith RD. Electrospray ionization mass spectrometry. Methods Enzymol 1990; 193: 412-55.

15 Möller G, Reck F, Paulsen H, et al. Control of glycoprotein synthesis: substrate specificity of rat liver UDPGynthesis: substrate specificity of rat liver UDPferase I using synthetic substrace analogues. Glycoconj $\mathcal{f}$ ferase I using synth

16 Palcic MM, Heerze LD, Pierce M, Hindsgaul O. The use of hydrophobic synthetic glycosides as acceptors in glycosyltransferase assays. Glycoconj $\mathcal{f} 1988$; 5: 49-63.

17 Bendiak B, Schachter H. Control of glycoprotein synthesis. XII. Purification of UDP-GlcNAc: $\alpha$-D-mannoside $\beta 1-2$ $\mathrm{N}$-acetylglucosaminyl-transferase II from rat liver. $\mathcal{f} \mathrm{Biol}$ Chem 1987; 262: 5775-83.

18 Bendiak B, Schachter H. Control of glycoprotein synthesis. XIII. Kinetic mechanism, substrate specificity, and inhibition characteristics of UDP-GICNAc: $\alpha$-D-mannoside $\beta 1-2-N$-acetylglucosaminyl-transferase II from rat liver. $\mathcal{F}$ Biol Chem 1987; 262: 5784-90.

19 Stibler H, Westerberg B, Hanefeld F, Hagberg B. Carbohydrate-deficient glycoprotein (CDG) syndrome a new variant, type III. Neuropediatrics 1993; 24: $51-2$

20 Spik G, Bayard B, Fournet B, Strecker G, Bouquelet S, Montreuil J. Studies on glycoconjugates. Complete structure of two carbohydrate units of human transferrin. FEBS Lett 1975; 50: 296-9.

21 Fukuda MN, Dell A, Scartezzini P. Primary defect of congenital dyserythropoietic anemia type II. Failure in glycosylation of erythrocyte lactosaminoglycan-proteins glycosylation of erythrocyte lactosaminoglycan-proteins
caused by lowered $\mathrm{N}$-acetylglucosaminyltransferase II. caused by lower $1987 ; 262$ : 7195-206.

22 Spik G, Debruyne V, Montreuil J, van Halbeek $H$, Vliegenthart JFG. Primary structure of two sialylated triantennary glycans from human transferrin. FEBS Lett 1985; 183: 65-9.

23 Schachter $\mathrm{H}$. Biosynthetic controls that determine the branching and microheterogeneity of protein-bound oligosaccharides. Biochem Cell Biol 1986; 64: 163-81.

24 Schachter $\mathrm{H}$. The 'yellow brick road' to branched complex N-glycans. Glycobiology 1991; 1: 453-61.

25 Schachter H, Brockhausen I, Hull E. High-performance liquid chromatography assays for $\mathrm{N}$-acetylglucosaminyltransferases involved in N- and O-glycan synthesis. transferases involved in $\mathrm{N}-$ and
Methods Enzymol 1989; 179: $351-96$.

26 Tan J, D'Agostaro GAF, Bendiak BK, Squire J, Schachter $\mathrm{H}$. Molecular cloning and localization to chromosome 14
of the human UDP-N-acetylglucosamine: $\alpha-6-D-m a n n o-$ side $\beta-1,2-N$-acetylglucosaminyltransferase II gene (MGAT2). Glycoconj $\mathcal{F} 1993$; 10: 232-3. 